Annals of Warsaw University of Life Sciences - SGGW

Land Reclamation No 38, 2007: 69-79

(Ann. Warsaw Univ. of Life Sci. - SGGW, Land Reclam. 38, 2007)

\title{
Laboratory assessment of permeability of a groundwater protective barrier
}

\author{
MIROSŁAW J. LIPIŃSKI, EUGENIUSZ KODA, \\ MAŁGORZATA K. WDOWSKA \\ Department of Geotechnical Engineering, Warsaw University of Life Sciences - SGGW
}

\begin{abstract}
Laboratory assessment of permeability of a groundwater protective barrier. The paper presents results of laboratory assessment of permeability of cement-bentonite self hardening mixtures which have recently been the most often used for construction of cut-off walls mitigating hazard of sanitary landfills. Laboratory tests were carried out on reconstituted and natural (undisturbed) material of the barrier. Due to the fact that actual permeability characteristics of reconstituted material are time and density dependent, changes of permeability are described against those variables. Comparison of these data with test results obtained for undisturbed material help to understand the process of changing properties of the barrier in the environment.
\end{abstract}

Key words: groundwater, protective barrier, permeability, undisturbed and reconstituted material.

\section{INTRODUCTION}

Thekeyissueconcerningsafemanagement of old sanitary landfills rests on reduction of any hazards resulting from undesired influence of these constructions on the local environment. The most popular and economically justified way of realisation of this objective leads to proper design of vertical cut-off walls which prevent horizontal transport of pollutants. In the design process of cut-off walls constructed in the subsoil of old sanitary landfill sourounding the key issue is a realistic assessment of geotechnical parameters of the barrier material. In geotechnical literature in the subject, the most often referred to parameter is coefficient of permeability. In the case of cement - bentonite mixtures it is important not only to determine permeability characteristics but also to monitor them during curing period of the material as well as assess the long term behaviour of the barrier.

To fulfill the above requirements, comprehensive laboratory test programme was undertaken aimed at evaluation of permeability at various stages of the barrier performance. Tests were carried out in triaxial apparatus on reconstituted and undisturbed samples. A special attention was drawn to quantitative description of change of these parameters in the self hardening mixture and comparison of the obtained values with those determined on undisturbed material. Samples of undisturbed hardened material were contrived from Radiowo landfill located near Warsaw. Detailed description of the landfill can be found in other paper of Koda et al. (2006). All laboratory tests were carried out in the Department of Geotechnical Engineering at Warsaw University of Life Sciences. 


\section{EXPERIMENTAL WORK}

\section{Material tested}

Tested material, known as SOLIDUR $274 \mathrm{~S}$, is commercially available in the form of powder. This material is a mixture based on cement and bentonite (mainly $\mathrm{Na}+$ ) with some special additives. Typical characteristics of the slurry eg. viscosity, liquid limit etc. depend strongly on density which results from proportion between dry mass of SOLIDUR and water. Recommended placement density of the slurry is in the range $1.15 \div 1.18$ $\mathrm{Mg} / \mathrm{m}^{3}$. However, due to inevitable sedimentation process which takes place in the field, the actual range of density can be wider, especially as higher values are concerned. With respect to this, reconstituted samples were prepared with initial densities being in the range $1.15 \div 1.29 \mathrm{Mg} / \mathrm{m}^{3}$.

\section{Test programme and procedures}

Permeability measurements were carried out in triaxial apparatus. The used triaxial cell has internal linking bars, what significantly facilitates access to a specimen during preparation. Six specimens were tested.

Three of them were trimmed from undisturbed material and three were reconstituted in a special mould assembled in the triaxial cell. Due to the fact that one of the objective of the experimental work was to monitor changes of permeability with respect to curing time and density of reconstituted material, permeability measurements were taken at several various stages of a curried sample. In the case of undisturbed samples, the actual permeability test was preceded by standard triaxial procedure ie. saturation and consolidation stage. As regards reconstituted samples, an initial part of the saturation stage (flushing) was not required since specimen prepared in a mould from a mixture was already fully saturated. The laboratory test programme of permeability tests is schematically shown in Figure 1.

In order to make reference to steady state seepage condition, the permeability tests were carried out on samples which were earlier saturated by back pressure elevated up to $300 \mathrm{kPa}$. The only exception referred to specimens tested for checking influence of not full saturation on permeability characteristics. When saturation stage was accomplished, each specimen was isotropically consolidated to effective stress of $150 \mathrm{kPa}$. As consolidation stage was terminated, the permeability test commenced. All permeability tests were carried out with use of flow pump technique (Aiban and Znidarcić, 1989).

This technique was especially designed for low permeability materials. The advantage of this method consists in entirely different philosophy of permeability measurement with respect to the steady gradient technique, that consists in the fact that in case of low permeability material, a measured volume of water coming out of a specimen is so small that accuracy of such measurement can not be accepted.

In the flow pump technique, the steady flow is imposed by variable speed motor driving single syringe infusion withdrawal pump. The measured value is pore pressure (head) generated at the bottom of a specimen during flow. From technical point of view it is much easier to 


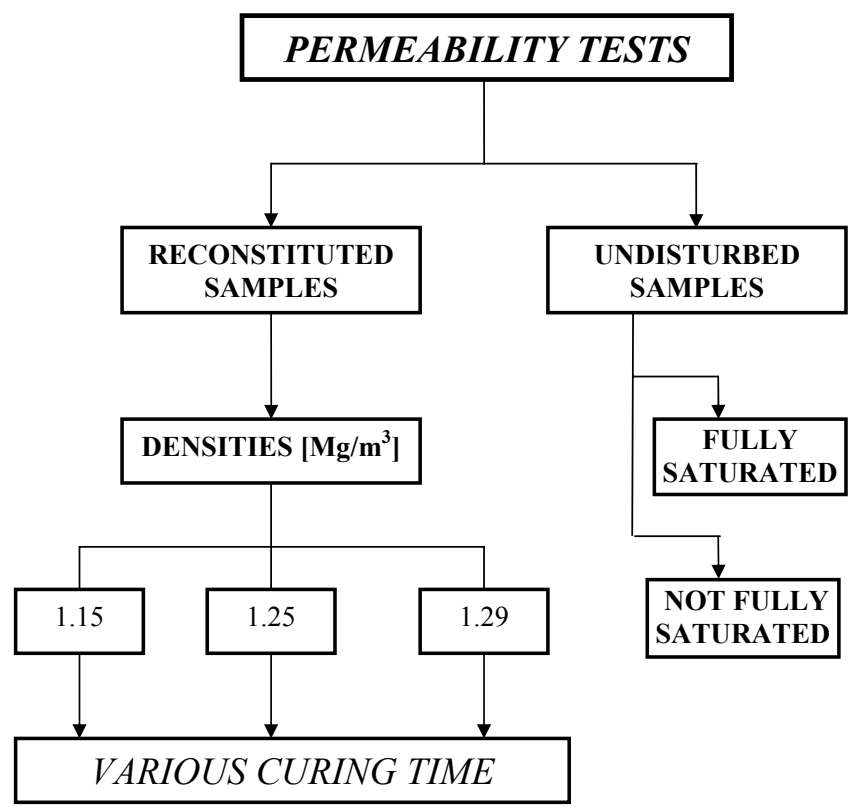

FIGURE 1. Laboratory test programme of permeability tests

measure pressure in the range of $150 \mathrm{kPa}$ than very small fraction of $1 \mathrm{ml}$ volume of water expelled from a specimen. Thus, accuracy of a measurement can be considerably enhanced. Application of various flow rates to the same specimen makes possible to obtain entire flow velocity - hydraulic gradient characteristics.

It is worth to emphasize, that measurement of permeability is carried out as a part of triaxial test, when values of vertical and horizontal stresses, as well as back pressure are controlled and values of vertical deformation and volume of water coming out of a specimen are measured. Laboratory set up of the whole permeability measurement system is shown in Figure 2.

\section{PERMEABILITY TEST CHARACTERISTICS}

As mentioned above, application of the flow pump technique considerable enhances accuracy of a measurement in determination of coefficient of permeability in cohesive soils. Besides, this technique delivers more information concerning the nature of change in permeability with curing time.

At first it is worth to consider how imposed flow of various rates changes pore pressure accumulated at the bottom of a specimen. An example of characteristics of distribution of accumulated head during flow pump tests for reconstituted material at various curing time is shown in Figure 3. The 


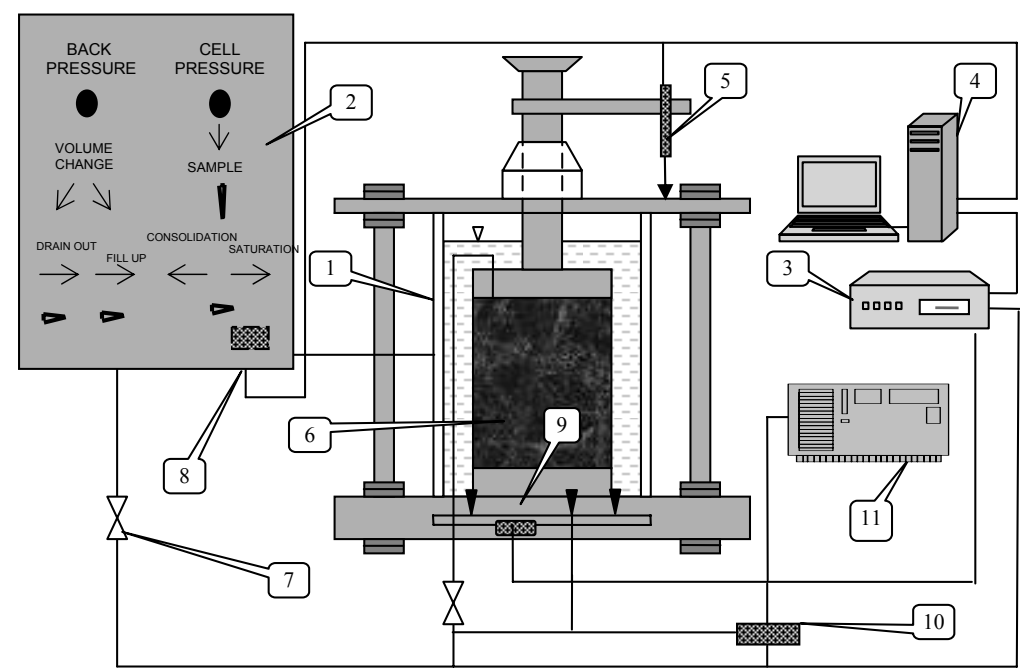

$1-$ triaxial cell

2 - control panel

3 - data logging system

4 - data logging system
5 - LVDT

6- a specimen

7 - ball valve

8 - cell presure transducer
9 - pore pressure transducer

10 - high resolution flow pump

11 - differential pressure transducer

FIGURE 2. Laboratory set up for permeability measurement in triaxial apparatus with use of flow pump technique

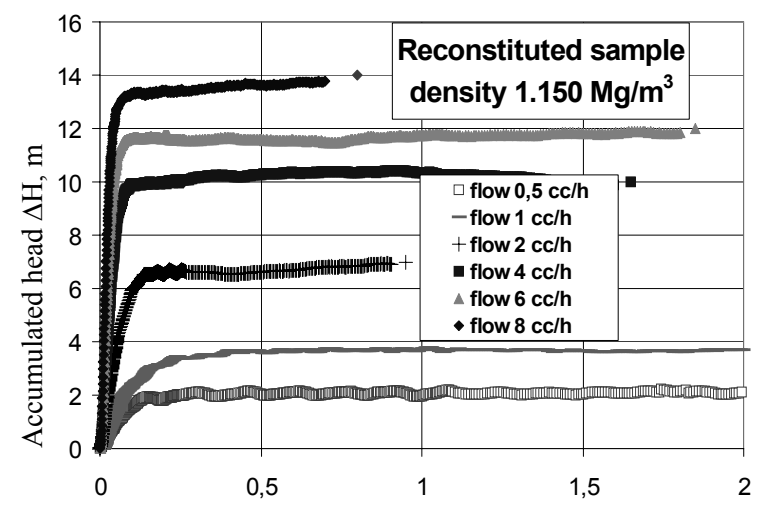

Time, hours

FIGURE 3. Typical characterisctics of pore pressure generation during permeability tests carried out on reconstituted sample (density $1.150 \mathrm{Mg} / \mathrm{m}^{3}$ )

characteristics shown in the chart concern a material of relatively low density $(1.15$ $\mathrm{Mg} / \mathrm{m}^{3}$ ) tested at early stage of curing time (9 days after placement of the slurry). The characteristics shown in the chart are very consistent ie. for higher flow rate, higher value of stabilised pore pressure is obtained. Also time required to achieve steady state as far as accumulated head is concerned is similar in all tests and it ranges 7-10 minutes. It can be also noticed that the higher flow rate the smaller is time required to stabilise the accumulated head. In general, it can 
be stated that characteristics are very smooth. Entirely different characteristics were obtained for other samples, having bigger densities of $1.25 \mathrm{Mg} / \mathrm{m}^{3}$ and 1.29 $\mathrm{Mg} / \mathrm{m}^{3}$ which were tested at various curing time (Fig. 4). Change in density required application of considerable reduced flow rates, at least of two orders of magnitude. Also time necessary for stabilisation of generated gradient was longer at least 200 times. Information given in the legend allows to contrive how curing time changes permeability characteristics. For instance, in the case of material having density $1.25 \mathrm{Mg} / \mathrm{m}^{3}$, 14 hours difference in curing time results in at least three- hour difference in time required to achieve steady state conditions of flow. Two other characteristics for higher density material also show strong dependence on curing time. Comparing respectively values of flow imposed, density of material and curing time, very high resolution of the flow pump technique can be confirmed.

\section{FACTORS AFFECTING PERMEABILITY}

\section{Degree of saturation}

When making an analysis of factors having influence on permeability assessment, the degree of saturation should be also considered (eg. Mitchell et al., 1965). This is particularly vital in cohesive soils, since due to unloading during sampling these soils are always not fully saturated before they are set up in an apparatus. This can be easy illustrated by characteristics of pore pressure generation during permeability tests on saturated and not fully saturated undisturbed sample of SOLIDUR, shown in Figure 5. Unsaturated soil characteristics are less regular, especially for small flow rates. For both unsaturated samples $\mathrm{Sr}<1$ conditions causes higher pore pressure generation, what simply means smaller coefficient of permeability. However, an inevitable question comes, how to ensure and then check that a mate-

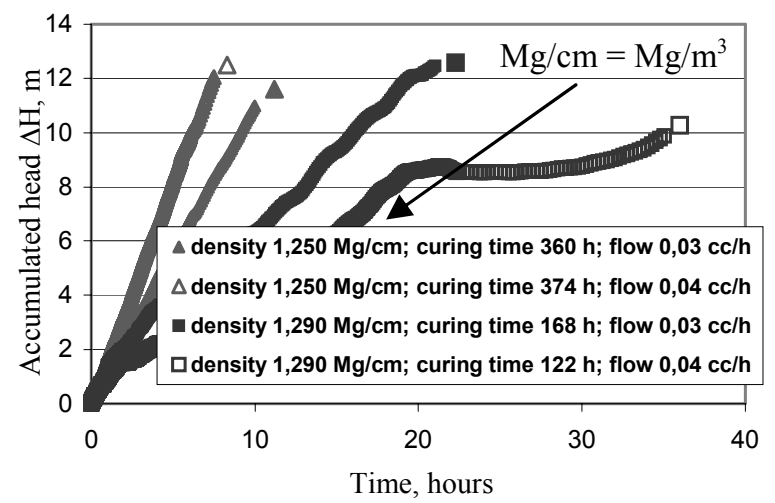

FIGURE 4. Influence of mixture density and curing time on pressure generation during flow pump test 
a

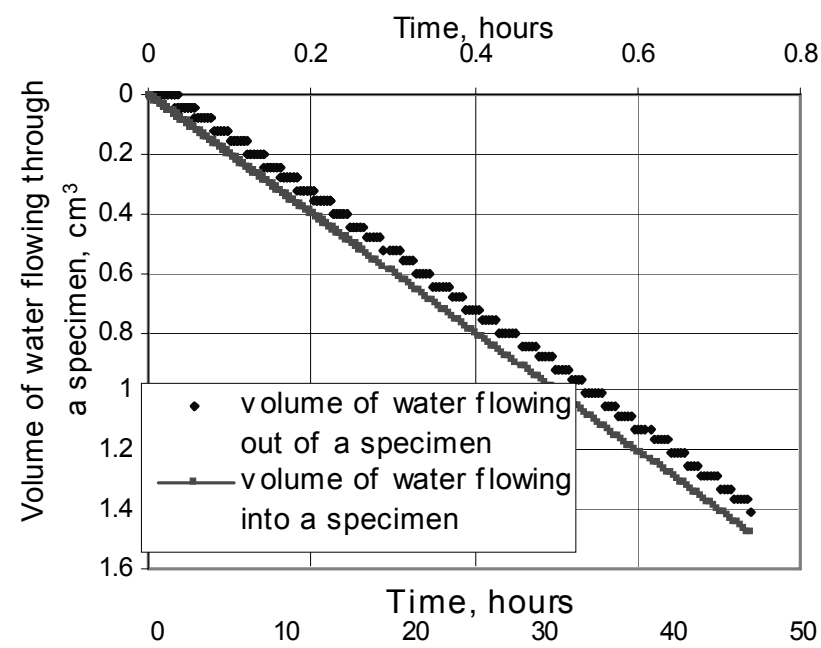

$\mathrm{b}$

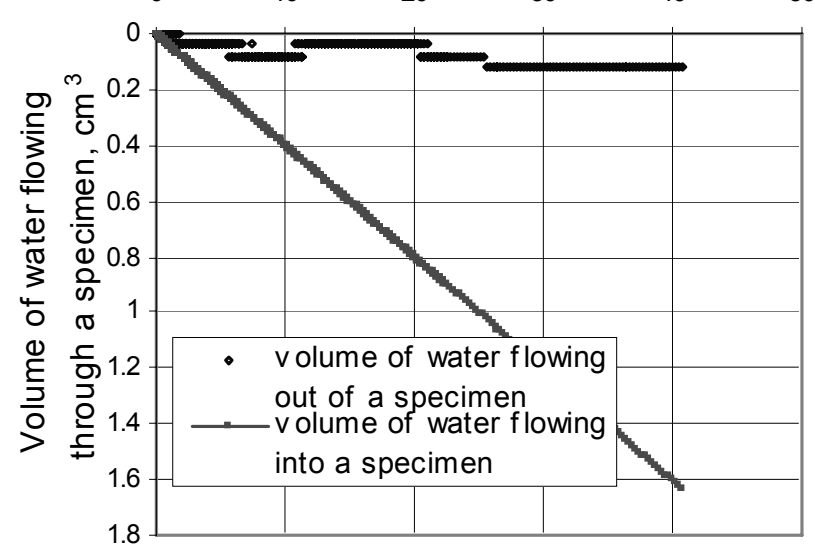

FIGURE 5. Verification of steady flow condi-tions for saturated (a) and not fully saturated sample (b)

rial is fully saturated? Rigorous requirement of high value (1 or close to 1 ) of B Skempton's parameter does not seem to be adequate, because of small compressibility of undisturbed SOLIDUR. Therefore in permeability tests another procedure of saturation check was adopted. This procedure, which takes advantage of the fact, that in saturated material imposed flow is realised in steady state conditions. It implies that volume of water flowing into a specimen must be equal to volume of water flowing out of it. Typical characteristics for saturated and unsaturated material are shown in Figure 6. It should be emphasized that, without verification of steady flow conditions any permeability tests can not be consider as a reliable.

However, what really counts is how not full saturation converts to permeability parameters. This is clearly illustrated in Figure 7, where flow velocities are drawn against stabilised hydraulic gradients for fully and not fully saturated undisturbed samples. 


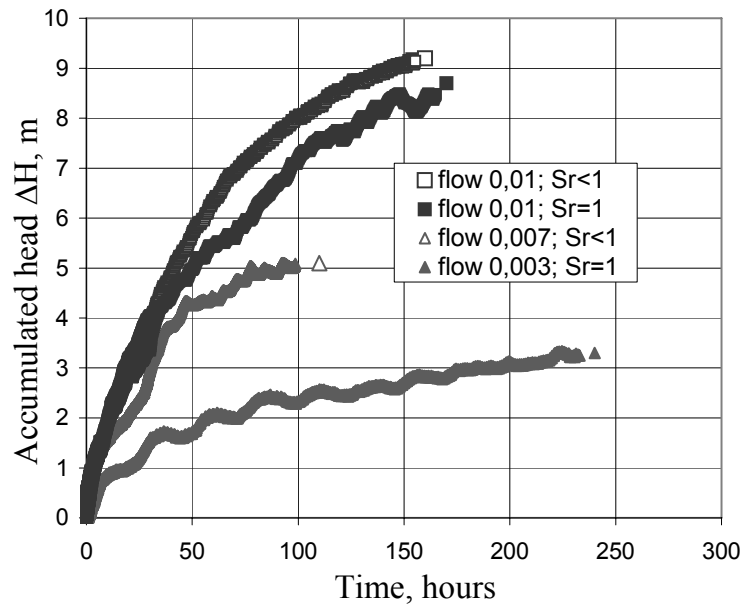

FIGURE 6. Pore pressure generation during permeability test on saturated and not fully saturated undisturbed samples

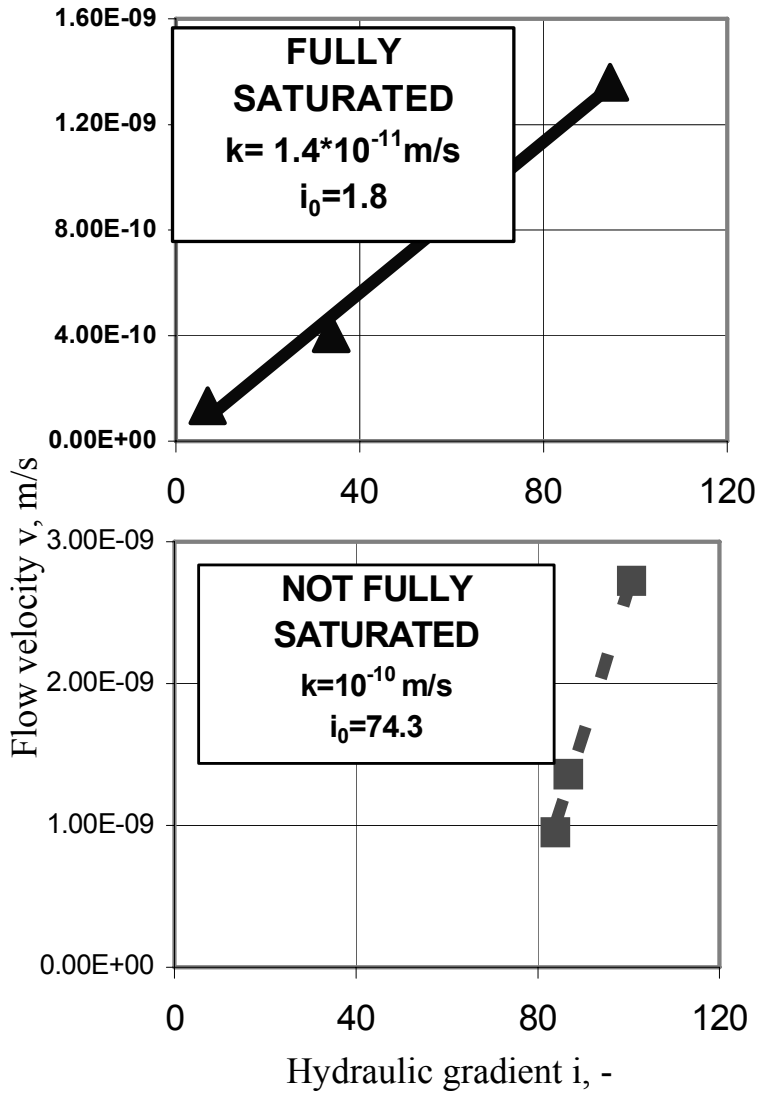

FIGURE 7. Permeability characteristics for fully and not fully saturated undisturbed samples 
Two flow characteristics depicted on the diagram explicitly show the difference in permeability parameters. Although coefficient of permeability $k$, which can be associated here with a slope of the regression line, for unsaturated material is almost one order higher $\left(10^{-10}>1.4\right.$. - $10^{-11} \mathrm{~m} / \mathrm{s}$ ), the initial gradient value $i_{o}$ is even more than 40 times greater. The initial value of hydraulic gradient changes from 1.8 for saturated material to 74.3 for unsaturated sample. If one converts these results to in situ conditions, it means that unsaturated material is practically impervious because in cutoff walls such high gradient as 74 is not feasible. Higher slope of regression line for unsaturated material results not from higher permeability but from unequal volume of water entering to a sample and coming out of it.

\section{Curing time and density}

Tests on reconstituted samples might reveal how curing time and density influence permeability of self hardening mixture prepared on the basis of SOLIDUR 247S.

Influence of curing time on permeability characteristics can be conveniently shown by comparison of characteristics of flow velocity against hydraulic gradient obtained for various curing time. In Figure 8 such characteristics are shown for sample having density $1.15 \mathrm{Mg} / \mathrm{m}^{3}$. For each curing time ie. 9,10 and 12 days after sample preparation, several permeability tests were carried out. As it results from the chart and the accompanying table, even small difference in curing time considerable change coefficient of permeability (slope of regression lines) and initial gradient. It is worth to emphasise that 3 days in

\begin{tabular}{|c|c|c|c|}
\hline No & $\begin{array}{r}\text { Curing } \\
\text { ti me }\end{array}$ & $\begin{array}{c}\text { Coefficient of } \\
\text { permeability }\end{array}$ & $\begin{array}{l}\text { Initial } \\
\text { gradient }\end{array}$ \\
\hline & $\boldsymbol{t}$ (days) & $\boldsymbol{k}(\boldsymbol{m} / \mathbf{s})$ & $\boldsymbol{i}_{\boldsymbol{o}}(-)$ \\
\hline 1 & 9 & $2.3 \cdot 10^{-8}$ & 1.4 \\
\hline 2 & 10 & $9.8 \cdot 10^{-9}$ & 17.5 \\
\hline 3 & 12 & $8.1 \cdot 10^{-9}$ & 29.6 \\
\hline
\end{tabular}

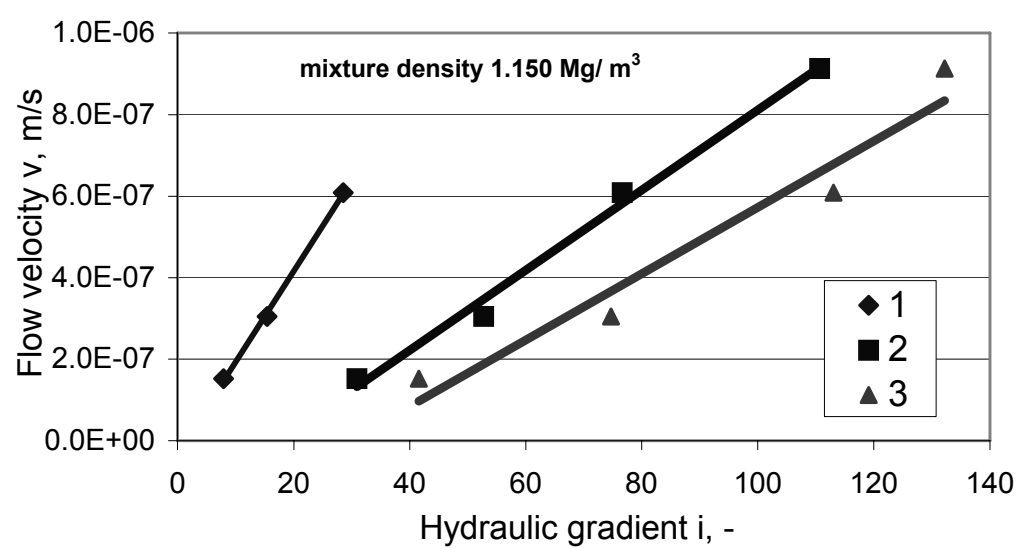

FIGURE 8. Influence of curing time on permeability characteristics of reconstituted sample 
curing time decreases almost three times coefficient of permeability and increases initial gradient more than 20 times. The later observation is of great practical importance.

In order to find out how placement density influences permeability of material it is convenient to present changes of coefficient of permeability against density of curing mixture (Fig. 9). Addition-

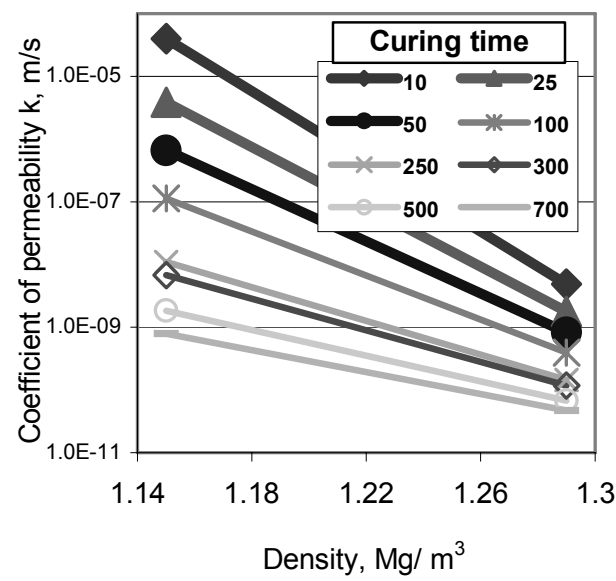

FIGURE 9. Evaluation of coefficient of permeability against density of mixture

ally, information concerning curing time was included in the chart. As it can be deduced from the characteristics shown in the figure, increase of density around $12 \%$ changes coefficient of permeability of several orders of magnitude, especially at early stages of hardening process. After one month of curing time, decrease in coefficient of permeability due to density increase is around 20 times.

\section{PERMEABILITY OF}

RECONSTRUCTED AND

\section{UNDISTURBED MATERIAL}

To summarise the above results it is important to compare them directly in order to see how permeability parameters changes for various sample of the same material: reconstituted and the natural one. In the Figure 10 such a comparison is presented for practically admissible values of hydraulic gradient. Surprisingly, all samples exhibit very small initial gradients from 0.3 to 1.8 . As far as coefficient of permeability is concerned, undisturbed material takes the lowest value. For material reconstituted in the laboratory, values of coefficient of permeability changes by magnitude of three orders (from $2.2 \cdot 10^{-8}$ to $2.4 \cdot 10^{-10}$ $\mathrm{m} / \mathrm{s}$ ), depending on the mixture density and curing time. These two variables are key parameters that contribute to mixture permeability and therefore they should be always analysed quantitatively. It should be emphasised that density of the wall in the field changes in profile with depth due to sedimentation process. Therefore to better understand the nature of permeability of the material, influence of curing time and mixture density should be separated. To realise this, permeability characteristics were determined for samples of different densities at varies curing time. Distribution of coefficient of permeability can be described by power equation:

$\mathrm{k}=\mathrm{a} t^{\mathrm{b}}$

where $a$ and $b$ are material constants dependent on density of the slurry.

Influence of density on value of coefficient of permeability is mostly pronounced at the beginning of curing time. In the example shown in Figure 11, difference in density of $0.14 \mathrm{Mg} / \mathrm{m}^{3}$ causes change in coefficient of permeability of four orders of magnitude. This difference decreases with time and after one month 


\begin{tabular}{|c|c|c|c|c|c|}
\hline No & Origin & Density & $\begin{array}{c}\text { Curing } \\
\text { time }\end{array}$ & $\begin{array}{c}\text { Coefficient of } \\
\text { permeability }\end{array}$ & $\begin{array}{c}\text { Initial } \\
\text { gradient }\end{array}$ \\
\hline & & $\rho\left(\mathrm{Mg} / \mathrm{m}^{3}\right)$ & $t$ (hours) & $\boldsymbol{k}(\mathrm{m} / \mathrm{s})$ & $\boldsymbol{i}_{\boldsymbol{o}}(-)$ \\
\hline 1 & reconstituted & 1.150 & 209 & $2.2 * 10^{-8}$ & 1.4 \\
\hline 2 & reconstituted & 1.290 & 115 & $2.4 * 10^{-10}$ & 0.3 \\
\hline 3 & undisturbed & 1.190 & - & $1.4 * 10^{-11}$ & 1.8 \\
\hline
\end{tabular}

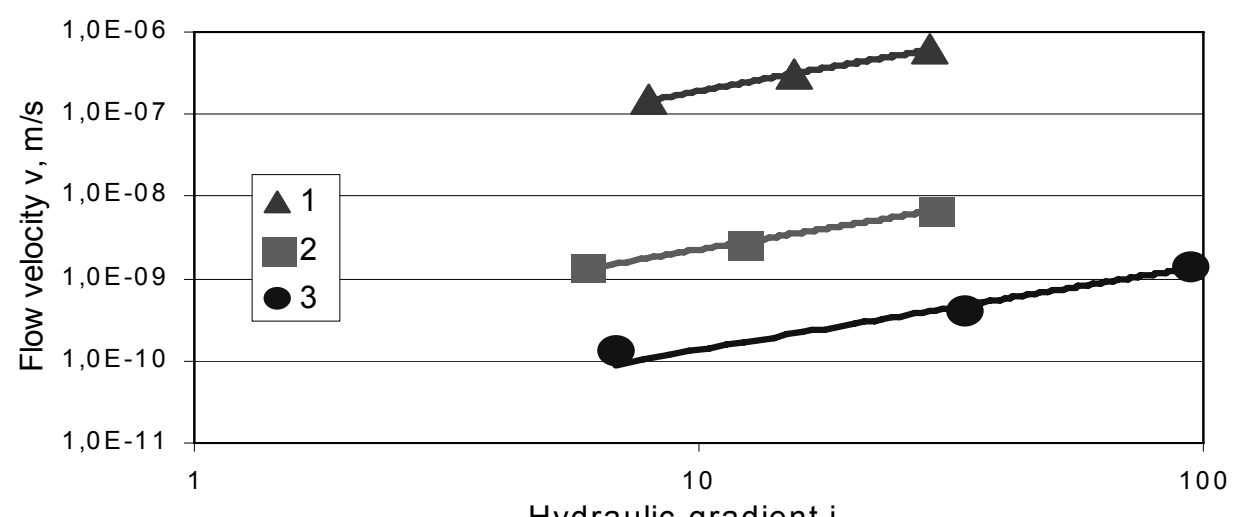

Hydraulic gradient i, -

FIGURE 10. Comparison of permeability characteristics for undisturbed and recontstituted samples

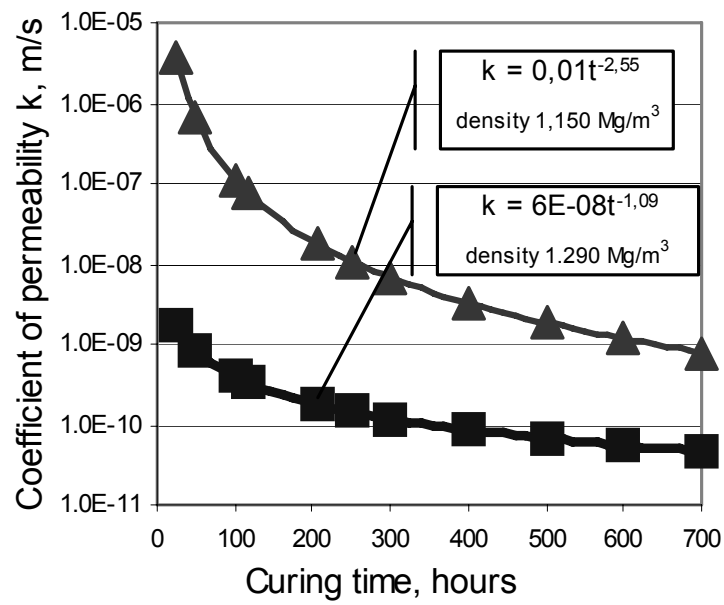

FIGURE 11. Prediction of change in coefficient of permeability with respect to curing time

\section{CONCLUSIONS}

coefficients of permeability are different only of one order of magnitude. Values of coefficient of permeability for various densities can be directly read from this chart.
The experimental programme carried out on reconstituted material of self hardening cement-bentonite mixture as well as on material sampled from the three years old cut-off wall, creates a certain 
contribution to understanding a process of permeability change of the barrier material. In particular, the following conclusions can be formulated:

- Coefficient of permeability of self hardening mixture changes intensively with density and curing time. It is possible to separate these variables and to set up formulae which make possible to calculate permeability of SOLIDUR 274S at any stage of hardening mixture and for any material density encountered in the field.

- Decrease in saturation of undisturbed material causes increase in initial gradient value from 1.8 to 74 what makes the material practically impervious.

\section{ACKNOWLEDGMENTS}

Some parts of experimental material gathered for preparation of this paper was financially supported by Polish Ministry of Scientific Research and Information Technology within the frame of the projects No 2P04G05627, NN506098933, NN506060333 and WULS (project numbers 504-05280016, 504-05280017).

\section{REFERENCES}

AIBAN S.A., ZNIDARČIĆ $\quad$ D. 1989: Evaluation of the flow pump and constant head techniques for permeability measurements. Géotechnique 39, Vol. 4, 655-666.
MITCHELL J.K., HOOPER D.R., CAMPANELLA R.G. 1965: Permeability of compacted clay. Journal of Soil Mechanics and Foundation Division. ASCE.

KODA E., WIENCŁAW E., KOŁANKA T. 2006: Assessment of reclamation efficiency of the old landfill on modelling and monitoring research. Proc. of the 5th International Congress on Environmental Geotechnics, Cardiff. Vol. I, 197-204.

Streszczenie: Ocena przepuszczalności przesłon przeciwfiltracyjnych $w$ świetle badań laboratoryjnych. W artykule przedstawiono wyniki badań laboratoryjnych, na podstawie których dokonano analizy i oceny przepuszczalności samotwardniejącej mieszaniny cementowo-bentonitowej. $\mathrm{W}$ ostatnim czasie, tego rodzaju materiał jest często wykorzystywany m.in. do konstrukcji przesłon przeciwfiltracyjnych zmniejszających zagrożenie pochodzące ze składowisk odpadów. Badania przeprowadzono na próbkach rekonstruowanych bezpośrednio w aparacie trójosiowym, a także na materiale o nienaruszonej strukturze pobranym z przesłony wykonanej w terenie. Przepuszczalność materiału rekonstruowanego określono w relacji do gęstości materiału i czasu jego tężenia od chwili przygotowania. Porównanie tych rezultatów z wynikami badań uzyskanymi na próbkach o nienaruszonej strukturze jest podstawą zrozumienia procesów zmiany właściwości filtracyjnych bariery przeciwfiltracyjnej w trakcie jej eksploatacji.

MS. received November 2007

\section{Authors' address:}

Mirosław J. Lipiński

Eugeniusz Koda

Małgorzata K. Wdowska

Katedra Geoinżynierii

Wydział Inżynierii i Kształtowania Środowiska, SGGW

02-776 Warszawa, Nowoursynowska 159,

Poland 